\title{
Dietary intake changes in adolescent girl after iron deficiency anemia diagnosis
}

DOI: dx.doi.org/10.22435/hsji.v11i1.3143

Dominikus Raditya Atmaka ${ }^{1}$, Windi Indah Fajar Ningsih ${ }^{2}$, Risnukathulistiwi Maghribi ${ }^{3}$

${ }^{1}$ Department of Health Nutrition, Faculty of Public Health, Universitas Airlangga

${ }^{2}$ Department of Nutrition, Faculty of Public Health, Universitas Sriwijaya

${ }^{3}$ Department of Health Nutrition, Faculty of Medicine, Public Health, and Nursing, Universitas Gadjah Mada

Corresponding author: Dominikus Raditya Atmaka

Email: dominikus.raditya@fkm.unair.ac.id

Received: April 17, 2020; Revised: May 14, 2020; Accepted: May 29, 2020.

\begin{abstract}
Abstrak
Latar Belakang: Defisiensi zat besi dapat terjadi karena rendahnya konsumsi makanan yang mengandung tinggi zat besi dan tingginya konsumsi makanan yang dapat menghambat absorpsi zat besi. Meningkatkan asupan zat gizi adalah salah satu cara paling efektif untuk memutus rantai permasalahan anemia defisiensi zat besi. Tujuan penelitian ini untuk mempelajari perubahan asupan gizi dan kesadaran akan kesehatan pada remaja perempuan sebelum dan setelah diagnosis anemia defisiensi besi.
\end{abstract}

Metode: Penelitian menggunakan desain kohort dengan subyek sebanyak 62 orang dari 2 Sekolah Menengah Pertama di Wates setelah dilakukan tes hemoglobin (metode cyanmethemoglobin) dan baru didiagnosis anemia defisiensi besi. Asupan energi, zat gizi makro (protein, lemak, karbohidrat), zat gizi mikro (zat besi, vitamin C, tembaga, zink, vitamin B12), faktor penghambat serapan (tanin, oksalat, fitat, serat), juga asupan, buah, sayur, kopi, dan teh diperoleh dengan semi quantitative food frequency questionnaire (SQFFQ), 3 bulan sebelum dan 3 bulan setelah diagnosis anemia defisiensi besi. Data dihitung dengan Nutrisurvey ${ }^{\circledR}$ and STATA $12^{\circledR}$ menggunakan paired T-test.

Hasil: Tidak ada perubahan signifikan ( $p>0,05)$ pada asupan energi, protein, lemak, zink, vitamin B12, tembaga, serat, tanin, dan oksalat. Terdapat peningkatan signifikan asupan karbohidrat ( $p=0,0161)$, zat besi $(p=0,0057)$, fitat $(p=0,000)$, dan vitamin $C(p=0,0017)$. Tidak ada perubahan signifikan rata-rata asupan buah, sayur, dan teh ( $p>0,05)$, tetapi konsumsi kopi lebih tinggi $(p=0,0018)$.

Kesimpulan: Diagnosis anemia defisiensi besi mengarahkan pada perubahan asupan zat gizi. Subyek menjadi lebih sadar pada asupan zat gizi setelah diagnosis anemia defisiensi besi. Dibutuhkan usaha lebih untuk merubah asupan buah dan sayur yang rendah dan konsumsi teh dan kopi yang tinggi. (Health Science Journal of Indonesia 2020;11(1):27-31)

Kata Kunci: perubahan asupan gizi, kebiasaan makan, remaja perempuan, anemia defisiensi zat besi

\begin{abstract}
Background: Iron deficiency may happen because of low consumption of foods rich in bioavailable iron and high consumption of foods rich in inhibitors of iron absorption. Improving dietary intake is the most effective way to break the chain of iron deficiency anemia problems. This study aimed to study the changes in dietary intake and health awareness among adolescent girl before and after iron deficiency anemia diagnosis.

Method: Cohort study with 62 subjects from 2 junior high school in Wates after hemoglobin test (cyanmethemoglobin method) and were newly iron deficiency anemia diagnosed. Intake of energy, macronutrient (protein, fat, carbohydrate), micronutrient (iron, vitamin C, Copper, Zinc, vitamin B12), inhibitor factors (tannin, oxalate, phytate, fiber), also intake of fruit, vegetable, coffee, and tea, collected using semi quantitative food frequency questionnaire (SQFFQ), 3 months before and 3 months after iron deficiency anemia diagnosis. Data calculated with Nutrisurvey ${ }^{\circledR}$ and STATA $12^{\circledR}$ for paired T-test.
\end{abstract}

Result: No significant changes ( $p>0,05)$ in energy, protein, fat, zinc, vitamin B12, copper, fiber, tannin, and oxalate intake. There were significant improvement in intake of carbohydrate $(p=0,0161)$, iron $(p=0,0057)$, phytate $(\mathrm{p}=0,000)$, and vitamin $\mathrm{C}(\mathrm{p}=0,0017)$. No significant changes in mean intake of fruit, vegetable, and tea servings $(p>0,05)$, but higher consumption of coffee $(p=0,0018)$.

Conclusion: Iron deficiency anemia diagnosis resulted in dietary intake changes. Subjects were more aware of their dietary intake after iron deficiency anemia diagnosis. Small fruit and vegetable intake and high tea and coffee consumption suggested that efforts were needed to encourage dietary changes in these foods. (Health Science Journal of Indonesia 2020;11(1):27-31)

Keywords: dietary changes, eating habit, adolescent girl, iron deficiency anemia 
Iron deficiency affects more than 2,2 billion people around the world, 15,6 percent of them are 12-19 y-old adolescent girl, and mostly coming from developing countries. ${ }^{1}$ Iron requirements are increased during adolescence time to fulfil growth spurt needs and replace menstrual losses. Iron requirements even higher in adolescents coming from developing countries because of some iron loss factor like infectious disease, parasitic infertation, and limited iron bioavailability in food. ${ }^{2}$

Iron deficiencies can decrease neuropsychologic function (psychomotor, mental, behavioral, and cognitive) also impair student work capacity (performance and achievement) in school. ${ }^{3}$ This impairment happens because iron deficiencies decrease number of dopamine D2 receptors and norepinephrine synthesis which resulted in residual abnormalities like sleep, learning, and memory disorders. ${ }^{2}$ Study by Dziembowska (2018) showed iron deficiency status in female were related to characteristics of electroencephalogram (EEG) and cognitive performance. ${ }^{4}$

Iron deficiency may happen because of low consumption of foods rich in bioavailable iron, high consumption of foods rich in inhibitors of iron absorption, such as phytate, inadequate intestinal iron absorption, or blood loss that associated to reduction of total body iron. ${ }^{5}$ If the iron deficiency continues for a longer time, synthesis of iron-containing protein like hemoglobin will fall below cut off value and progressed to iron deficiency anemia. Improving dietary intake is the most effective way to break the chain of iron deficiency anemia problems. Dietary changes act as a complement of pharmacological therapy by providing additional nutrients and preventing adverse interaction between dietary supplements and food. ${ }^{6}$ Therefore, we conduct this study to assess the changes in dietary intake and health awareness among adolescent girls before and after iron deficiency anemia diagnosis.

\section{METHODS}

This research was a prospective pre-post test cohort study conducted from January to June 2016 in Wates, Kulon Progo, Special Region of Yogyakarta, Indonesia. Research has been approved by Ethical Board of the Faculty of Medicine, Universitas Gadjah Mada with Ethical Clearance number KE/ FK/655/EC June 10, 2015.

The population of this study was female students between 12-15 years old from 2 junior high schools in Wates, Kulon Progo (SMPN 2 Wates and SMPN 3 Wates). These junior high schools were randomly chosen from 8 junior high school in Wates, Kulon Progo. All subjects were randomly chosen using Microsoft Excel ${ }^{\circledR}$ and agree to join the study by signed informed consent approved by the Institutional Review Board of the Faculty of Medicine, Universitas Gadjah Mada. Based on Slovin formula, minimum subjects included in the study were 62 (52 students with additional of 20 percent loss to follow up).

Iron deficiency anemia status was determined by performing blood hemoglobin test (cyanmethemoglobin method) and serum ferritin test (ELISA method) in Biochemistry Laboratory, Faculty of Medicine, Universitas Gadjah Mada. Anemia assessment was held in Januari 2016. Subjects were selected if values of blood test were abnormal for age group 12-18 year old (hemoglobin < $12 \mathrm{~g} / \mathrm{dL}$ and serum ferritin $<15 \mu \mathrm{g} / \mathrm{L}$ ). Students were chosen if they were newly iron deficiency anemia diagnosed and have not taken any medication related to iron deficiency anemia diagnosis. Demographic characteristic data were collected using paper based questionnaire. To measure the changes of dietary, intake of energy, macronutrient (protein, fat, carbohydrate), micronutrient (iron, vitamin C, Copper, Zinc, vitamin B12), inhibitor factors (tannin, oxalate, phytate, fiber), and intake of fruit, vegetable, coffee, and tea, were collected using semi quantitative food frequency questionnaire (SQFFQ), 3 months before and 3 months after iron deficiency anemia diagnosis. All data were administered by nutritionist during school days.

Data were calculated using Nutrisurvey ${ }^{\circledR}$ and STATA $12 \AA$. Demographic characteristics data were analyzed descriptively. Dietary changes were tested using paired T-test. Results were statistically significant if $\mathrm{p}<0,05$.

\section{RESULTS}

Among 189 schoolgirls, 69 were newly diagnosed with iron deficiency anemia (incidence $=36,5$ percent), but 7 students refused to participate in the study. Most subjects came from middle low income family with family income less than 2 million rupiah. Subject parents were mostly well educated with average finished senior high school. Based on screening results, hemoglobin mean of subjects were $10,365 \mathrm{~g} / \mathrm{dL}$ and serum ferritin mean was $8,885 \mu \mathrm{g} / \mathrm{L}$. 
Table 1. Demographic Characteristic of Adolescent Girl

\begin{tabular}{|c|c|}
\hline Characteristic & $\mathrm{n}(\%)$ \\
\hline \multicolumn{2}{|l|}{ Living place } \\
\hline With parents & $54(87,10)$ \\
\hline With grandparents & $5(8,06)$ \\
\hline Dormitory & $3(4,84)$ \\
\hline \multicolumn{2}{|l|}{ Family income per month } \\
\hline$<1$ million rupiah & $22(35,48)$ \\
\hline 1-2 million rupiah & $35(56,45)$ \\
\hline$>2$ million rupiah & $5(8,06)$ \\
\hline \multicolumn{2}{|c|}{ Mother formal educational background } \\
\hline Not finish primary school & $5(8,06)$ \\
\hline Finish primary school & $15(24,19)$ \\
\hline Finish junior high school & $11(17,74)$ \\
\hline Finish senior high school & $25(40,32)$ \\
\hline Finish university & $6(9,68)$ \\
\hline \multicolumn{2}{|c|}{ Father formal educational background } \\
\hline Not finish primary school & $9(14,52)$ \\
\hline Finish primary school & $10(16,13)$ \\
\hline Finish junior high school & $10(16,13)$ \\
\hline Finish senior high school & $29(46,77)$ \\
\hline Finish university & $4(6,45)$ \\
\hline \multicolumn{2}{|l|}{ Mother occupation } \\
\hline Not working (stay at home) & $34(54,84)$ \\
\hline Government employee & $4(6,45)$ \\
\hline Private employee & $2(3,23)$ \\
\hline Other & $22(35,48)$ \\
\hline \multicolumn{2}{|l|}{ Father occupation } \\
\hline Government employee & $6(9,68)$ \\
\hline Private employee & $4(6,45)$ \\
\hline Entrepreneur & $10(16,13)$ \\
\hline Other & $42(67,74)$ \\
\hline \multicolumn{2}{|l|}{ Menstruation status } \\
\hline Already menstruating & $40(64,51)$ \\
\hline Still not menstruating & $22(35,48)$ \\
\hline \multicolumn{2}{|l|}{ Menstruation regularity } \\
\hline Regular & $31(77,5)$ \\
\hline Irregular & $9(22,5)$ \\
\hline \multicolumn{2}{|l|}{ Menstruation duration } \\
\hline 3-5 days & $27(67,5)$ \\
\hline More than 5 days & $13(32,5)$ \\
\hline
\end{tabular}

Based on dietary survey using semi quantitative food frequency questionnaire, there were no significant changes $(p>0,05)$ in energy, protein, fat, zinc, vitamin $\mathrm{B} 12$, copper, fiber, tannin, and oxalate intake before and after iron deficiency anemia diagnosis. But there was significant improvement $(p<0,05)$ in the intake of carbohydrate, iron, phytate, and vitamin $\mathrm{C}$ after iron deficiency anemia diagnosis. There are no significant changes $(\mathrm{p}>0,05)$ in the mean intake of fruit, vegetable, and tea servings, but higher consumption of coffee $(p=0,0018)$.

\section{DISCUSSION}

Adolescence characterized by large growth spurt and during this period iron requirements increase as result of increase lean body mass and onset of menstruation. ${ }^{7}$ Overall daily iron requirements increase to as much as $26 \mathrm{mg}$ per day. Based on assessment, there were improvements in iron dietary intake after diagnosis, but subjects still consumed less than $19 \mathrm{mg}$ iron per day which indicates negative iron balance. Iron food is divided into two forms, iron heme and iron nonheme. More than 40 percent of iron in meat are iron heme (protoporphyrin iron) with 15-35 percent bioavailability, which is present in meat, poultry, and seafood. ${ }^{1}$ Most iron in diet is iron nonheme (found in pulse, grain, and fruit) with 5-20 percent bioavailability depends on iron facilitators and inhibitors of absoption. ${ }^{6}$

Table 2. Dietary Changes Before and After Iron Deficiency Anemia Diagnosis

\begin{tabular}{|c|c|c|c|}
\hline & $\begin{array}{l}\text { Before Diagnosis } \\
\qquad(n=62)\end{array}$ & $\begin{array}{l}\text { After Diagnosis } \\
\qquad(n=62)\end{array}$ & p-value \\
\hline Energy (kkal) & $1517,95 \pm 56,96$ & $1616,87 \pm 60,92$ & 0,1201 \\
\hline $\begin{array}{l}\text { Carbohydrate } \\
\text { (g) }\end{array}$ & $264,10 \pm 9,29$ & $288,71 \pm 11,24$ & $0,0161^{*}$ \\
\hline Protein (g) & $47,37 \pm 2,66$ & $46,66 \pm 2,31$ & 0,8233 \\
\hline Fat $(\mathrm{g})$ & $33,19 \pm 2,11$ & $35,19 \pm 2,32$ & 0,4438 \\
\hline Iron (mg) & $16,33 \pm 0,95$ & $19,81 \pm 1,12$ & $0,0057^{*}$ \\
\hline Tanin (mg) & $7495,37 \pm 480,12$ & $7779,00 \pm 668,18$ & 0,6904 \\
\hline Oxalate (mg) & $0,14 \pm 0,02$ & $0,13 \pm 0,02$ & 0,7176 \\
\hline Phytate (mg) & $284,93 \pm 21,29$ & $439,73 \pm 26,78$ & $<0,0001^{*}$ \\
\hline $\begin{array}{l}\text { Vitamin C } \\
(\mathrm{mg})\end{array}$ & $92,19 \pm 11,81$ & $165,06 \pm 23,68$ & $0,0017^{*}$ \\
\hline Copper (mg) & $8,89 \pm 5,06$ & $6,10 \pm 5,17$ & 0,5141 \\
\hline Zinc (mg) & $1,07 \pm 0,21$ & $1,03 \pm 0,24$ & 0,8389 \\
\hline $\begin{array}{l}\text { Vitamin B12 } \\
(\mathrm{mg})\end{array}$ & $3,63 \pm 0,49$ & $2,77 \pm 0,27$ & 0,1040 \\
\hline Fiber $(\mathrm{g})$ & $7,51 \pm 0,51$ & $9,10 \pm 0,86$ & 0,0508 \\
\hline Vegetable (g) & $113,06 \pm 14,13$ & $116,79 \pm 21,56$ & 0,8319 \\
\hline Fruit (g) & $150,00 \pm 16,17$ & $155,55 \pm 21,87$ & 0,8202 \\
\hline Coffee (ml) & $14,17 \pm 3,68$ & $35,52 \pm 7,03$ & $0,0018 *$ \\
\hline Tea $(\mathrm{ml})$ & $155,41 \pm 16,82$ & $149,83 \pm 19,24$ & 0,7954 \\
\hline
\end{tabular}

$*)=$ p-value significant $(\mathrm{p}<0,05)$

Iron deficiency anemia is a common problem in adolescent group due to improper diet and lack of nutrition awareness. Prevention, detection, or management effort of anemia in adolescent until now are not received much attention. ${ }^{8}$ Family ability to buy iron rich foods, family health awareness, and family health knowledge are defining factors of iron deficiency anemia. Most subjects in this study were coming from low income family and cannot afford to buy high quality iron source foods in daily basis. Inadequate intake of iron because of household insecurity of food resulted in iron deficiency anemia. ${ }^{9}$ Parents educational background also define subjects awareness to health. Most subjects were thinking that iron deficiency anemia is not an issue that need higher 
attention, so that subjects were having little tendency to change their eating habits. Besides diet factors, unhealthy household environment and inadequate health service (poor hygiene, environmental sanitation and waste disposal) also can influencing high prevalence of iron deficiency anemia. ${ }^{9}$

Positive changes happen in vitamin $\mathrm{C}$ intake which can enhance absorption of iron. Subjects tend to have higher vitamin $\mathrm{C}$ consumption after they were diagnosed having iron deficiency anemia. This may related to several factors such as increased knowledge and perception of vitamin $\mathrm{C}$ health benefits or other dietary behaviors, so that they can increase their hemoglobin level. In fact, some food component can promote absoption of iron almost 3 times like ascorbic acid. ${ }^{10}$ But there also some components inhibit absoption of iron especially nonheme iron like phytates (5 and 6 phosphate inositol) from cereal, legume, and nut products, coffee, tea, milk, dietary fibers, lignins, phenolic polymers, products of nonenzymatic Maillard browning, phosphate containing carbonated beverages, multivitamin containing calcium, zinc, manganese, or copper, usage of antacid, $\mathrm{H} 2$ blocker, pump inhibitors, and tetracycline. ${ }^{2,11}$

Giving iron deficiency anemia diagnosis did not change subjects dietary patterns on food components that can inhibit absorption of iron. Subjects still have drunk tea and coffee habit after eating that can add the negative impact of iron deficiency anemia. Insufficient iron intake and high iron inhibitor intake (like phytate and tannin) will make subjects susceptible to iron deficiency anemia because of low iron store. ${ }^{10}$ Tannin and catechin in tea can inhibit bioavailability of non heme iron by 79-84 percent. $^{12}$ Increased consumption of coffee can reduce serum ferritin by 18,8 percent. Coffee intake reduced absorption of non heme iron by 40 percent. ${ }^{13}$ Tea and coffee consumption with meals are not recommended for people suffering from anemia.

The diet survey in subjects indicated poor intake of green leafy vegetables, fruits, and iron rich foods. Data from Health Behaviour in SchoolAged Children (HBSC) also showed that fruit and vegetable consumption tends to decrease between ages 11 and 15 because increased autonomy in food choice. ${ }^{14}$ Adolescents are taking control of what, when, and where they eat and typically consume a greater proportion of their total food intake outside home. Their concern about body shape and adiposity also changes adolescent eating behaviour. ${ }^{15}$ This is attributed to modernization influences which given subject choose more fast food and following fads diets, so that subject was more likely to consume less nutritious foods like vegetable and fruit.

Dietary pattern problems in adolescents are determined by some factors such as low knowledge of parents, low parental and peers support, low family income, poor eating attitude, missing family meals, and increasing food and snack consumption out of home. ${ }^{16}$ Family meals are important key in adolescent food intake because it is time to socialize and teach them eating habits and proper nutrition. Adolescents who share more than 3 times family meals a week more likely to have healthier dietary pattern and less likely to have eating disorder. ${ }^{17}$

Adolescents who eat out of home frequently and missed family meals are having poor quality of diet including low consumption of fruit, vegetable, and dairy products. Parent educational background is related to adolescents diet quality and healthy eating. Adolescents with higher parental educational background consumed higher fruit and vegetable than adolescents with lower parental educational level. This could also happen because socio-economic status, especially low income and low accessibility to healthy diet. Parents with lower educational level gave less attention to their children which conclude to higher incidence of missing family meals and higher incidence of eating out of home. ${ }^{18}$

In conclusion, iron deficiency anemia diagnosis resulted in dietary intake changes. Subjects were more aware of their dietary intake after iron deficiency anemia diagnosis. Small fruit and vegetable intake and high tea and coffee consumption suggested that efforts were needed to encourage dietary changes in these foods. Subjects should be encouraged to increase their diet with foods rich in heme iron, such as red meat (full of hemoglobin and myoglobin) or liver. Vitamin C is also needed to increase iron absorption and can be increased in diet by addition of fruits. Tea consumption can inhibit iron absorption. So iron deficiency person needs to wait for 1 to 2 hours after meals before consuming tea or even remove tea from their diet. Further research should be conducted in wider community settings to cover non-school going girls.

\section{Acknowledgements}

The author would like to thank all participants and supervisor from Nutrition and Health Department at Faculty of Medicine, Public Health, and Nursing, Universitas Gadjah Mada, for their support this 
study as part of larger study in iron fortification in iron deficiency anemia adolescent girl.

\section{REFERENCES}

1. Lopez M, Cacoub P, Macdougall IC, Peyrin-Biraulet L. Iron deficiency anemia. Lancet. 2016; 387:907-16.

2. Barragan-Ibanez G, Santoyo-Sanchez A, RamosPenafiel CO. Iron deficiency anemia. Rev. Med. Hosp. Gen. Mex. 2016;79(2):88-97.

3. Haas JD, Brownlie T. Iron deficiency and reduced work capacity: a critical review of the research to determine a causal relationship. J. Nutr. 2001;131:676S-690S.

4. Dziembowska I, Kwapisz J, Izdebski P, Zekanowska E. Mild iron deficiency may affect female endurance and behavior. Phsy. Beh. 2018;205:44-50.

5. Camaschella C. New insights into iron deficiency and iron deficiency anemia. Blood Reviews. 2017;31:225-33.

6. Santoyo-Sanchez A, Aponte-Castillo JA, Parra-Pena RI, Ramos-Penafiel CO. Dietary recommendations in patients with deficiency anaemia. Rev. Med. Hosp. Gen. Mex. 2015;78(3): 144-50.

7. Dennison RP. Adolescence. in the wiley blackwell encyclopedia of family studies, first edition. New Jersey: John Wiley \& Sons; 2016.

8. Chaturvedi D, Chaudhuri PK, Priyanka, Chaudhary AK. Study of correlation between dietary habits and anemia among adolescent girls in Ranchi and its surrounding area. Int. J. Contemp. Pediatr. 2017;4(4):1165-8.

9. Bailey RL, West Jr. KP, Black RE. The epidemiology of global micronutrient deficiencies. Ann. Nutr. Metab. 2015;66(Suppl 2):22-3.
10. Wong C. Iron deficiency anaemia. J. Paed. 2017; 08.004:1-3.

11. Alleyne M, Horne MK, Miller JL. Individualized treatment for iron-deficiency anemia in adults. The American Journal of Medicine. 2018;121:943-8.

12. Hayat K, Iqbal H, Malik U, Bilal U, Mushtaq S. Tea and its consumption: benefit and risks. Critical Reviews in Food Science and Nutrition. 2013;55(7):939-54.

13. Sung ES, Choi CK, Kim NR, Kim SA, Shin MH. Association of coffee and tea with ferritin: data from the Korean National Health and Nutrition Examination Survey (IV and V). Chonnam Med. J. 2018;54:178-83.

14. Currie C, Zanotti C, Morgan A, Currie D, Looze MD, Roberts C. Social determinants of health and well being among young people: health behaviour in SchoolAged Children (HSC) study: international report from the 2009/2010 Survey. Copenhagen: Health Policy for Children and Adolescents; 2012.

15. Cruz F, Ramos E, Lopes C, Araujo J. Tracking of food and nutrient intake from adolescence into early adulthood. Nutrition. 2018;55-56:84-90.

16. Cutler GJ, Flood A, Hannan P, Neumark-Sztainer D. Multiple sociodemographic and socioenvironmental characteristics are correlated with major patterns of dietary intake in adolescents. Journal of the American Dietetic Association. 2011 Feb;111(2):230-40.

17. Hammons AJ, Fiese BH. Is frequency of shared family meals related to the nutritional health of children and adolescents? Pediatrics. 2011;127(6):e1565-74.

18. Tajik E, Latiffah AL, Awang K, Asyura ASN, Chin YS, Shah ABA, et al. Unhealthy diet practice and symptoms of stress and depression among adolescents in Pasir Gudang, Malaysia. Obes. Res. Clin. Pract. 2015;10:114-23. 